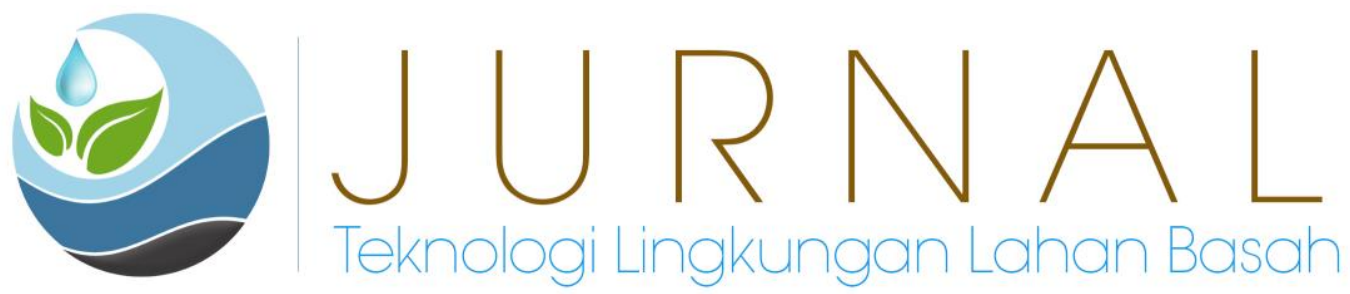

\title{
EFEKTIVITAS PENGGUNAAN PASIR KERANG SEBAGAI MEDIA PENGOLAHAN AIR GAMBUT MENJADI AIR BERSIH
}

\author{
Daud Perdana ${ }^{1}$, Suhendra $^{1^{*}}$ \\ ${ }^{1}$ Jurusan Teknik Mesin, Politeknik Negeri Sambas \\ *E-mail : aka.suhendra@yahoo.com
}

\begin{abstract}
Residents in Sambas Regency generally utilizing well water and river water to meet the needs of clean water. One of the materials that used in processing of clean water is sand clamshell. The Sand clamshell is used because the abundant availability and is often found along the coast, but its effectiveness has not been tested. The object of this research is to test the effectiveness of sand clamshell in reducing color levels and increasing the $\mathrm{pH}$ value of peat water. When the water coming out of the installation was varied into 9 treatments, namely 0, 5, 10, 20, 40, 60, 90, 180 and 360 minutes. Based on the test results, sand clamshell is effective used to treat peat water into clean water. The best test results for sand clamshell are obtained when the water first exits from water treatment plant $(0$ minutes) with the effectiveness of color absorption of 29.9\%, from 1,420 Pt.Co to 995 Pt.Co, while pH increases from 4.23 to 7.38. The effectiveness of the sand clamshell has decreased with the length of time in the processing of peat water.
\end{abstract}

Keywords: color; peat water; pH; sand clamshell

\begin{abstract}
Abstrak
Masyarakat di Kabupaten Sambas umumnya memanfaatkan air sumur dan air sungai untuk memenuhi kebutuhan air bersih. Salah satu media yang digunakan dalam mengolah air bersih adalah pasir kerang. Pasir kerang digunakan karena ketersediannya yang melimpah dan banyak ditemui di sepanjang pesisir pantai, namun pengujian efektivitasnya masih belum dilakukan. Penelitian ini bertujuan untuk menguji efektivitas pasir kerang dalam menurunkan kadar warna dan meningkatkan nilai $\mathrm{pH}$ air gambut. Waktu air keluar dari instalasi divariasikan menjadi 9 perlakuan yaitu 0, 5, 10, 20, 40, 60, 90, 180 dan 360 menit. Berdasarkan hasil pengujian, pasir kerang efektif digunakan untuk mengolah air gambut menjadi air bersih. Hasil pengujian terbaik untuk pasir kerang diperoleh pada saat air pertama kali keluar dari instalasi pengolah air (0 menit) dengan efektivitas penjerapan warna 29,9\% yaitu dari 1.420 Pt.Co menjadi 995 Pt.Co, sedangkan pH mengalami peningkatan dari 4,23 menjadi 7,38. Efektivitas kerja pasir kerang mengalami penurunan seiring dengan lamanya penggunaan pasir kerang dalam pengolahan air gambut.
\end{abstract}

Kata Kunci : warna, air gambut; pH; pasir kerang 


\section{PENDAHULUAN}

Meningkatnya pertumbuhan penduduk menyebabkan kebutuhan akan air bersih semakin meningkat. Air bersih merupakan salah satu kebutuhan pokok manusia yang dibutuhkan secara berkelanjutan. Pentingnya kebutuhan akan air bersih menyebabkan sektor ini wajib mendapatkan prioritas penanganan utama karena menyangkut kehidupan orang banyak.

Pemenuhan kebutuhan air khusunya masyarakat di Kabupaten Sambas umumnya masih memanfaatkan air sumur dan air sungai karena layanan PDAM hanya bisa memenuhi sebagian kecil suplai air bersih. Air tanah yang terdapat di wilayah Sambas sebagian besar berupa air gambut dengan kondisi fisik air berwarna kuning terang, coklat atau merah kehitaman dengan kadar pH rendah (Suhendra dkk., 2016).

Air gambut adalah air permukaan yang terdapat pada lahan gambut dengan ciri-ciri berasa asam, mengandung zat organik dan zat besi tinggi, memiliki $\mathrm{pH}$ rendah (3-5), memiliki tingkat kesadahan rendah, berwarna coklat, merah atau kehitaman. Lahan gambut terbentuk dari sisa tumbuhan yang telah atau belum membusuk, serta memiliki kandungan organik tinggi (Suhendra dan Rianto, 2017). Air gambut secara umum tidak memenuhi persyaratan kualitas air bersih seperti yang disyaratkan oleh Departemen Kesehatan RI melalui PERMENKES No. 416/MENKES/PER/IX/1990. Menurut Widayat dan Said (2001), sulitnya pemenuhan kebutuhan air bersih dan buruknya kualitas lingkungan dapat memunculkan masalah lain yang lebih kompleks seperti timbulnya berbagai masalah kesehatan pada masyarakat.

Berbagai penelitian tentang pengolahan air gambut telah banyak dilakukan. Penelitian tentang penggunaan arang aktif tempurung kelapa telah dilakukan untuk menguji kadar warna dan $\mathrm{pH}$ air gambut. Hasil penelitian tersebut menunjukkan bahwa arang aktif tempurung kelapa dapat meningkatkan nilai $\mathrm{pH}$ air gambut sampai 1,55 dan dapat menurunkan kadar warna air gambut sampai 41,06\% (Suhendra dkk., 2016)

Muchlis dkk., (2017), memanfaatkan cangkang kerang darah (anadara granosa) dan zeolit sebagai media filter keramik untuk pengolahan air gambut. Hasil penelitian tersebut dapat menaikkan $\mathrm{pH}$ dan menurunkan logam besi dan zat organik. Filter keramik dengan perbandingan cangkang kerang darah dan zeolit 75\%:25\% efektif menaikkan $\mathrm{pH}$ dari 4,4 menjadi 6,7 dan menurunkan logam besi sebesar 15,6\% sedangkan filter keramik dengan perbandingan cangkang kerang darah dan zeolit 25\%:75\% dapat menurunkan zat organik sebesar $3,8 \%$.

Rais dkk., (2017), melakukan penelitian tentang pengolahan air gambut menggunakan sistem filtrasi dengan media cangkang kerang darah, zeolite, karbon aktif dan pasir halus. Hasil penelitian tersebut mampu meningkatkan kualitas air gambut. Efektivitas penurunan masing - masing parameter kualitas air gambut hasil penelitian adalah kekeruhan sebesar 95,45\%, pH sebesar 57,89\%, besi (Fe) sebesar 72,78\% dan zat organik sebesar $85,57 \%$.

Sumiharni dan Susilo (2009), meneliti penggunaan campuran dosis tawas, batu kapur dan kaporit. Berdasarkan hasil pengujian, dosis yang lebih efektif adalah penggunaan dosis tawas $0,5 \mathrm{gr} / \mathrm{L}$, batu kapur $0,1 \mathrm{gr} / \mathrm{L}$, dan kaporit $0,05 \mathrm{gr} / \mathrm{L}$ untuk menghasilkan parameter COD, TSS, Amonia Nitrogen dan DO yang memenuhi kriteria baku mutu air domestik kelas II non konsumsi.

Media yang umumnya digunakan dalam pengolahan air gambut adalah karbon aktif, zeolite, manganese, resin dan pasir kuarsa. Media lain yang juga banyak digunakan adalah 
kulit kerang dan biji kelor namun media ini perlu diolah terlebih dahulu sebelum digunakan sebagai pengolah air. Selain itu, media obsorben seperti tawas, kapur dan kaporit juga sering ditambahkan untuk mengolah air bersih.

Media alternatif lain yang dapat digunakan untuk pengolahan air bersih adalah pasir kerang. Pasir kerang banyak digunakan warga Sambas untuk mengolah air bersih. Penggunaan pasir kerang sangat dimungkinkan karena ketersediaannya yang melimpah. Pasir kerang banyak ditemui di pesisir pantai wilayah Kabupaten Sambas dan Singkawang. Pasir kerang terbentuk dari campuran pasir pantai dan berbagai kulit kerang, memiliki ukuran partikel relatif lebih besar dari pasir biasa, berbentuk kasar dengan warna coklat kekuningan. Selama ini, efektivitas kinerja pasir kerang dalam pengolahan air bersih masih belum diuji. Berdasarkan kondisi tersebut, penelitian ini mengupayakan pengujian efektivitas kinerja media berupa pasir kerang untuk pengolahan air gambut.

\section{METODE PENELITIAN}

Tahap pelaksanaan penelitian dilakukan dengan membuat instalasi pengolahan air gambut, membuat rancangan percobaan, melakukan pengujian, mengambil data dan menganalisis data untuk membuktikan hubungan antar variabel penelitian.

Arah aliran air gambut dalam pengujian dapat dilihat pada Gambar 1. Aliran proses pengolahan air dimulai dari air gambut yang ditampung pada bak penampungan awal berkapasitas 800 Liter. Air gambut selanjutnya dialirkan menuju tabung pengolah air. Arah aliran air gambut mengikuti desain dengan arah aliran dari atas ke bawah pada pipa bagian dalam dan menuju ke atas pada pipa bagian luar. Arah aliran tersebut untuk memaksimalkan kontak antara media penjernih dan air gambut.

Alat yang digunakan dalam penelitian ini adalah instalasi pengolah air gambut, wadah ukur $1000 \mathrm{~mL}$, stopwatch, botol plastik dan corong. Bahan uji dalam penelitian ini adalah air gambut yang diambil dari Desa Kartiasa Kecamatan Sambas.

Prosedur pengujian dilakukan dengan menentukan variabel bebas dan variabel tak bebas yang digunakan dalam penelitian. Variabel bebas penelitian adalah jenis media pengolah air gambut dan waktu aliran air keluar dari instalasi pengolah air gambut. Media utama penelitian untuk pengolahan air gambut adalah pasir kerang, sedangkan pasir kuarsa dan karbon aktif hanya sebagai data pembanding. Pasir kuarsa dan karbon aktif yang digunakan adalah bahan yang terdapat di pasaran, sedangkan pasir kerang diambil dari pesisir pantai Desa Semelagi Kecil Kecamatan Singkawang Utara.

Ukuran butir pasir kerang, pasir kuarsa dan karbon aktif yang digunakan diseragamkan dengan melakukan pengayakan menggunakan 2 buah ayakan berbeda ukuran. Ayakan pertama berukuran 4 mesh $(4,75 \mathrm{~mm})$ sedangkan ayakan kedua berukuran 40 mesh $(0,425 \mathrm{~mm})$. Ukuran butir yang digunakan adalah butir yang lolos dari ayakan 4 mesh dan tertahan pada ayakan 40 mesh. 


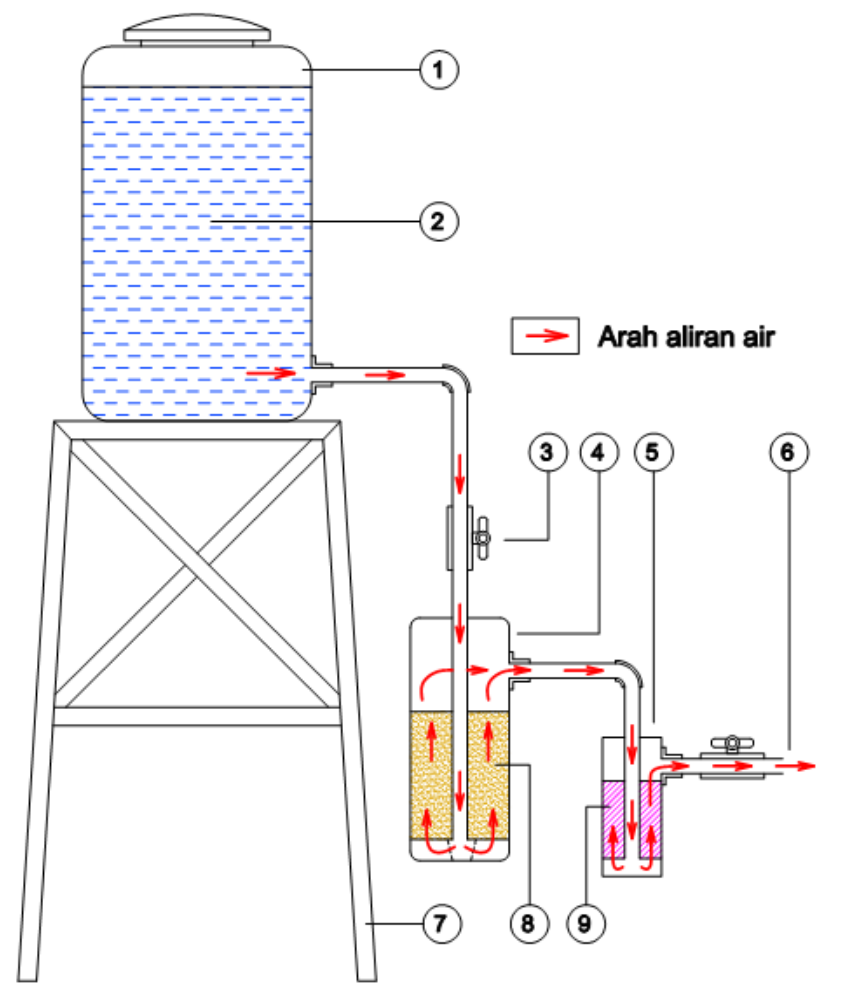

Keterangan Gambar :

1. Bak penampungan

2. Air gambut

3. Stop kran

4. Tabung pengolah air gambut

5. Tabung filter

6. Saluran keluar

7. Rangka dudukan bak

8. Media pengolah air

9. Filter

Gambar 1. Arah aliran air gambut dalam instalasi

Waktu air keluar dari instalasi divariasikan menjadi 9 perlakuan yaitu 0, 5, 10, 20, 40, 60, 90, 180 dan 360 menit. Variabel tak bebas penelitian adalah parameter warna dan pH air gambut setelah melalui proses pengolahan. Pada bagian akhir instalasi terdapat filter berukuran 1 micron berfungsi untuk menyaring kotoran atau media pembersih yang ikut terbawa aliran air.

Pengujian terhadap masing-masing media pengolah air gambut dilakukan dengan 3 pengulangan. Sebelum media pengolah air gambut digunakan, cuci terlebih dahulu menggunakan air bersih. Pengujian warna dari sampel air gambut yang telah diolah ditentukan dengan spektrofotometri pada panjang gelombang $450 \mathrm{~nm}-465 \mathrm{~nm}$ menggunakan larutan standar Pt.Co. Pengukuran nilai warna sebenarnya (true color) berdasarkan hukum Beers (SNI, 2011).

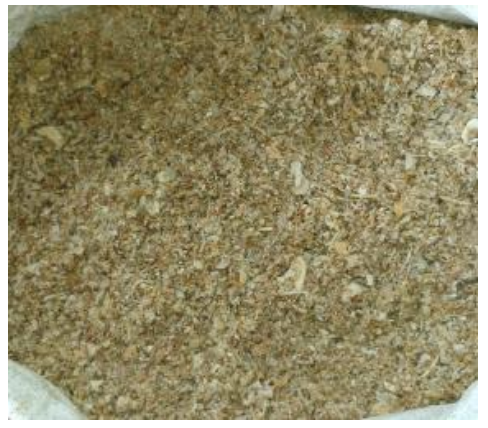

(a)

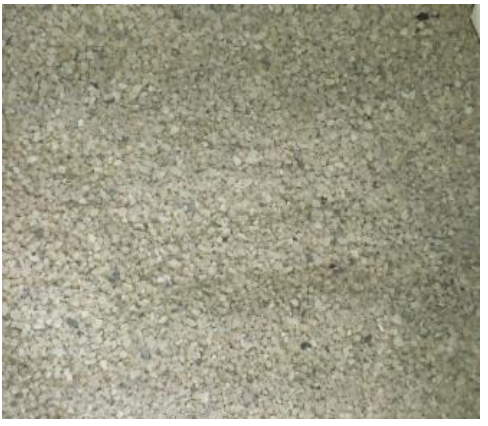

(b)

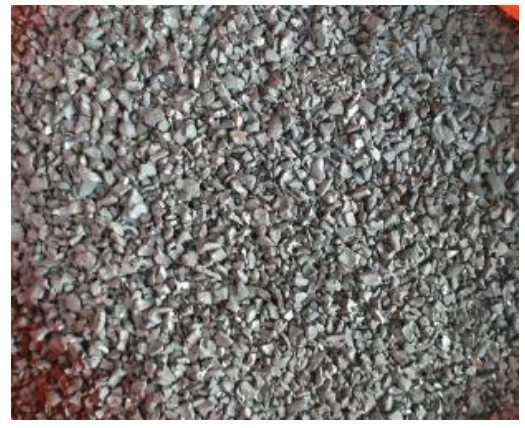

(c)

Gambar 2. Media pengolah air gambut yang digunakan, (a) pasir kerang, (b) pasir kuarsa, (c) karbon aktif

Efektivitas pasir kerang untuk menurunkan warna air dianalisis dengan persen penjerapan. Persen penjerapan dihitung dengan persamaan berikut (Suhendra dkk, 2016): 
Penjerapan $(\%)=\frac{C_{o}-C_{e}}{C_{o}} \times 100 \%$

Keterangan :

$\mathrm{Co}=$ Konsentrasi awal warna (Pt.co)

$\mathrm{Ce}=$ Konsentrasi akhir warna (Pt.co)

Pengukuran $\mathrm{pH}$ air gambut yang telah diolah dilakukan dengan mengukur $\mathrm{pH}$ air gambut sebelum masuk ke instalasi pengolah air kemudian dibandingkan dengan $\mathrm{pH}$ air setelah keluar dari instalasi pengolah air berdasarkan waktu pengolahan yang telah ditentukan.

\section{HASIL DAN PEMBAHASAN}

Pengukuran kadar $\mathrm{pH}$ dan warna air gambut dilakukan di Badan Penelitian dan Pengembangan Industri, Balai Riset dan Standarisasi Industri Pontianak. Hasil pengukuran air gambut tanpa perlakuan diperoleh nilai $\mathrm{pH} 4,23$ dan warna 1.420 Pt.Co.

Rata-rata debit aliran air yang digunakan dalam penelitian adalah sebesar 3,53 liter/menit. Jumlah media yang digunakan untuk mengolah air gambut dalam satu kali pengujian sebanyak 5 liter.

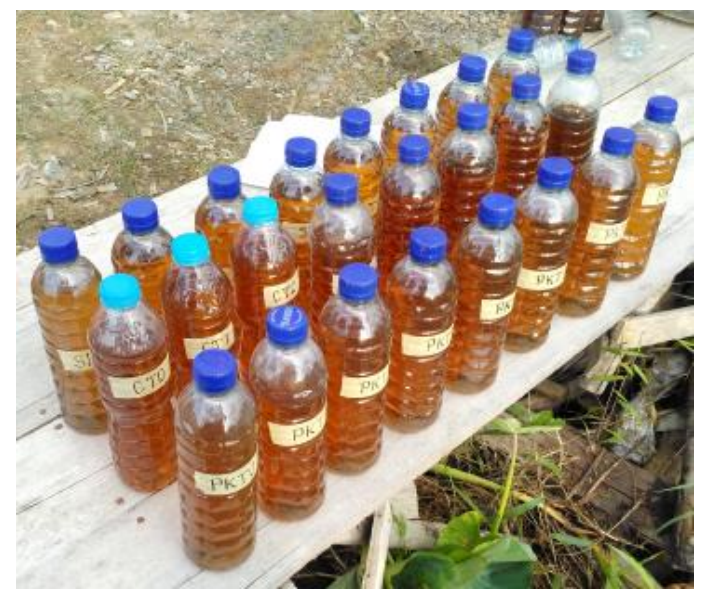

Gambar 3. Sampel hasil pengujian

Hasil pengujian menunjukkan bahwa waktu air gambut keluar dari instalasi pengolahan air memiliki pengaruh terhadap perubahan warna air gambut. Air gambut yang keluar pertama kali (0 menit) dari instalasi pengolahan air rata-rata memiliki tingkat penurunan kadar warna paling tinggi. Air gambut yang keluar pertama kali melalui media pasir kerang, pasir kuarsa dan karbon aktif mengalami penurunan kadar warna masing-masing sebesar $29,9 \%, 29,3 \%$ dan $26,3 \%$. 
Tabel 1. Hasil pengujian pasir kuarsa, pasir kerang dan karbon aktif terhadap warna air gambut

\begin{tabular}{cccc}
\hline \multirow{2}{*}{$\begin{array}{c}\text { Waktu } \\
\text { (menit) }\end{array}$} & \multicolumn{3}{c}{ Media Pengolah Air Gambut } \\
\cline { 2 - 4 } & $\begin{array}{c}\text { Pasir } \\
\text { kuarsa }\end{array}$ & $\begin{array}{c}\text { Pasir } \\
\text { kerang }\end{array}$ & $\begin{array}{c}\text { Karbon } \\
\text { aktif }\end{array}$ \\
\cline { 2 - 4 } & \multicolumn{2}{c}{ Kadar warna (Pt.Co) } \\
\hline 0 & 1.004 & 995 & 1.047 \\
\hline 5 & 1.082 & 1.070 & 1.118 \\
\hline 10 & 1.082 & 1.117 & 1.250 \\
\hline 20 & 1.111 & 1.128 & 1.258 \\
\hline 40 & 1.163 & 1.128 & 1.281 \\
\hline 60 & 1.216 & 1.152 & 1.293 \\
\hline 90 & 1.262 & 1.163 & 1.314 \\
\hline 180 & 1.307 & 1.187 & 1.342 \\
\hline 360 & 1.392 & 1.254 & 1.405 \\
\hline TP & & 1.420 & \\
\hline
\end{tabular}

Keterangan : TP = Air gambut tanpa perlakuan

Efektivitas penurunan kadar warna pada penelitian ini lebih rendah dari penelitian Makhmudah dan Notodarmojo (2010), yang memakai saringan pasir lambat 2 tingkat pada air sungai dengan kadar awal 59-343 mg/L Pt.Co, memiliki efektivitas penyerapan sebesar $52 \%$. Nilai efektivitas penyerapan ini lebih besar disebabkan kondisi air baku yang digunakan memiliki kadar warna yang relatif rendah.

Efektivitas pasir kerang, pasir kuarsa dan karbon aktif sebagai media pengolah air gambut semakin berkurang untuk menurunkan kadar warna air gambut seiring dengan lamanya penggunaan media tersebut. Pada menit ke 360, pasir kuarsa dan karbon aktif sudah hampir tidak memiliki kemampuan untuk menurunkan kadar warna air gambut, sedangkan pasir kerang masih memiliki kemampuan untuk menurunkan kadar warna air gambut sebesar 11,7\%. Hasil pengujian ini sesuai dengan penelitian Rachmah dan Porwoto (2014), yang menyatakan bahwa semakin lama proses filtrasi menyebabkan penurunan persentase efektivitas media tersebut.

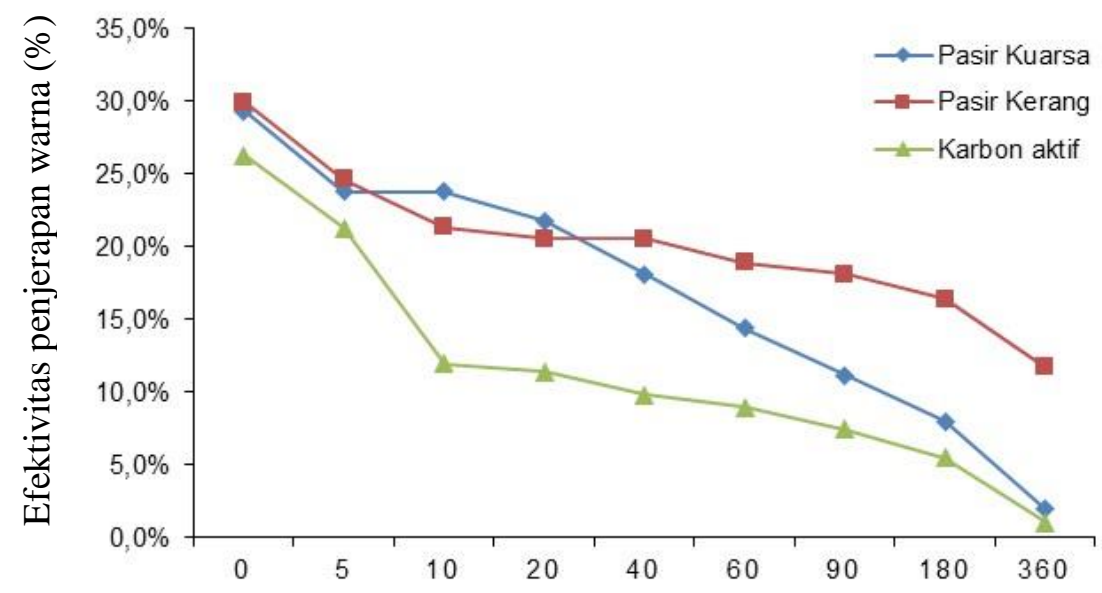

Waktu air keluar instalasi pengolahan (menit)

Gambar 4. Hubungan antara waktu air keluar instalasi pengolahan dengan persentase penjerapan warna 
Efektivitas rata-rata pasir kerang dalam menurunkan kadar warna air gambut berkurang sebesar 3,03\% dalam satu jam, sedangkan pasir kuarsa dan karbon aktif masing-masing berkurang sebesar 4,55\% dan 4,20\% dalam satu jam. Hal ini menunjukkan bahwa pasir kerang memiliki kemampuan yang lebih baik dari pasir kuarsa dan karbon aktif dalam proses penjerapan warna air gambut. Hubungan antara waktu air keluar instalasi pengolahan dengan persentase penjerapan warna dapat dilihat pada Gambar 4.

Hasil pengujian pasir kerang, pasir kuarsa dan karbon aktif terhadap kenaikan $\mathrm{pH}$ air gambut rata-rata memiliki pengaruh terbesar pada awal air keluar dari instalasi pengolahan air. Nilai $\mathrm{pH}$ air gambut yang keluar dari instalasi pengolah air pada waktu 0 menit dengan media pasir kerang, pasir kuarsa dan karbon aktif adalah masing-masing sebesar 7,38, 7,24 dan 7,17.

Lamanya penggunaan media pengolah air gambut tersebut memiliki pengaruh terhadap penurunan efektivitas untuk meningkatkan kadar $\mathrm{pH}$ air. Penggunaan pasir kuarsa selama 360 menit sudah tidak efektif digunakan untuk meningkatkan nilai $\mathrm{pH}$ air, sedangkan pasir kerang dan karbon aktif masih dapat digunakan walaupun efektivitas kerja media tersebut sudah mengalami penurunan. Efektivitas rata-rata pasir kerang, pasir kuarsa dan karbon aktif dalam meningkatkan nilai $\mathrm{pH}$ air gambut masing-masing berkurang sebesar 0,26, 0,36 dan 0,17 dalam 1 jam. Hasil pengujian pasir kuarsa, pasir kerang dan karbon aktif dalam meningkatkan $\mathrm{pH}$ air gambut dapat dilihat pada Tabel 2.

Tabel 2. Hasil pengujian pasir kuarsa, pasir kerang dan karbon aktif terhadap $\mathrm{pH}$ air gambut

\begin{tabular}{cccc}
\hline \multirow{2}{*}{$\begin{array}{c}\text { Waktu } \\
\text { (Menit) }\end{array}$} & \multicolumn{3}{c}{ Media Pengolah Air Gambut } \\
\cline { 2 - 4 } & $\begin{array}{c}\text { Pasir } \\
\text { kuarsa }\end{array}$ & $\begin{array}{c}\text { Pasir } \\
\text { kerang }\end{array}$ & $\begin{array}{c}\text { Karbon } \\
\text { aktif }\end{array}$ \\
\cline { 2 - 4 } & \multicolumn{3}{c}{ pH } \\
\hline 0 & 7,24 & 7,38 & 7,17 \\
\hline 5 & 6,63 & 7,30 & 7,02 \\
\hline 10 & 6,45 & 6,92 & 6,98 \\
\hline 20 & 6,24 & 6,81 & 6,91 \\
\hline 40 & 6,17 & 6,69 & 6,76 \\
\hline 60 & 5,92 & 6,55 & 6,64 \\
\hline 90 & 5,78 & 6,33 & 6,42 \\
\hline 180 & 5,35 & 6,12 & 6,35 \\
\hline 360 & 5,11 & 5,84 & 6,17 \\
\hline TP & \multicolumn{3}{|}{4,23} \\
\hline
\end{tabular}

Keterangan $: \mathrm{TP}=$ Air gambut tanpa perlakuan

Berdasarkan hasil pengujian terhadap efektivitas peningkatan $\mathrm{pH}$ air gambut, karbon aktif dan pasir kerang memiliki efektivitas yang hampir sama sedangkan pasir kuarsa memiliki efektivitas yang lebih rendah dari kedua media tersebut. Rata-rata efektivitas peningkatan kadar $\mathrm{pH}$ yang dihasilkan sebesar 35,62\%, sedikit lebih rendah dibanding penelitian Rais dkk. (2017) dengan efektivitas peningkatan pH sebesar 57,89\%.

Hasil penelitian menunjukkan bahwa, pasir kerang sangat efektif digunakan untuk pengolahan air gambut menjadi air bersih. Pasir kerang baik digunakan untuk menurunkan kadar warna dan meningkatkan nilai $\mathrm{pH}$ air gambut. Hasil pengujian terbaik 
menggunakan pasir kerang diperoleh pada saat air gambut pertama kali keluar dari instalasi pengolahan air dengan efektivitas penjerapan warna 29,9\% dan kemampuan peningkatan $\mathrm{pH}$ dari 4,23 menjadi 7,38. Efektivitas pasir kerang untuk pengolahan air gambut akan berkurang seiring dengan lamanya penggunaan untuk mengolah air, sehingga lama penggunaan pasir kerang memiliki pengaruh signifikan terhadap mutu air bersih yang dihasilkan. Hubungan antara waktu air keluar instalasi pengolahan dengan perubahan $\mathrm{pH}$ dapat dilihat pada Gambar 5.

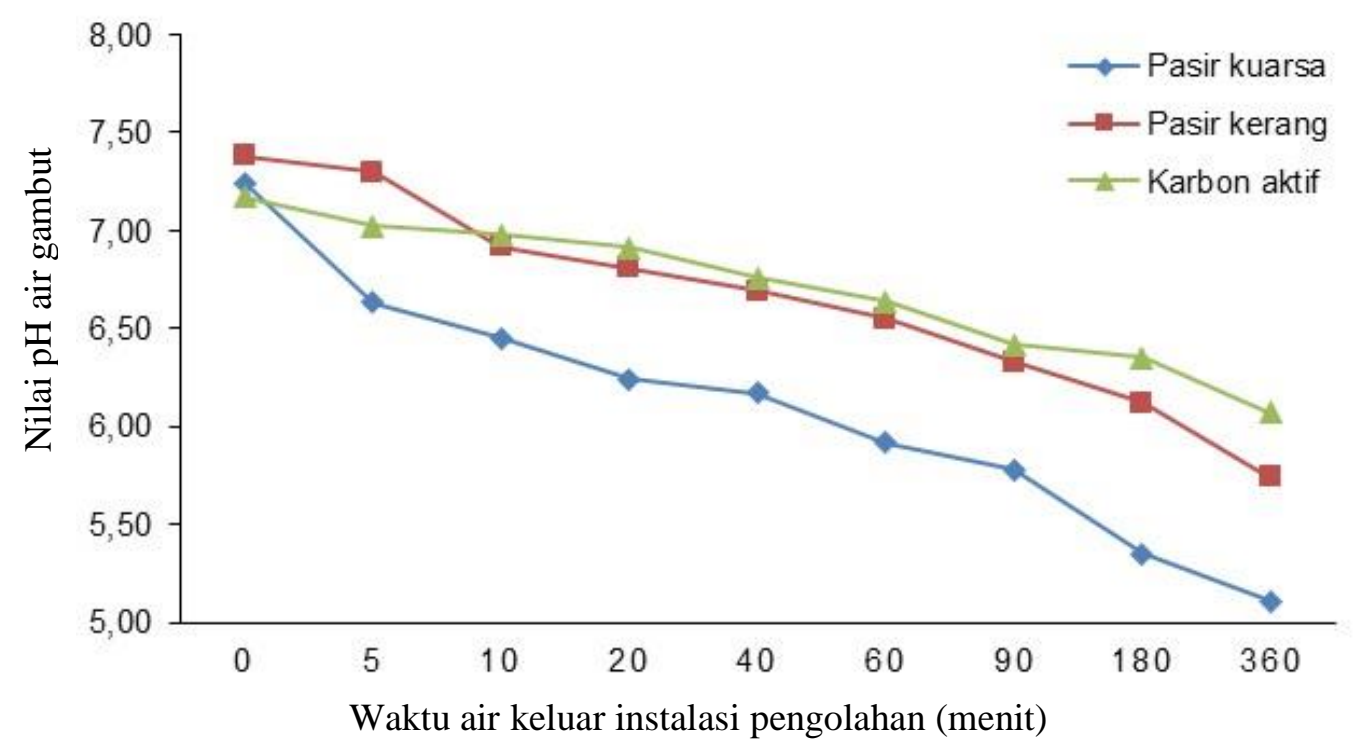

Gambar 5. Hubungan antara waktu air keluar instalasi pengolahan terhadap perubahan $\mathrm{pH}$ air

Efektivitas media pembersih untuk pengolah air juga dipengaruhi oleh jenis air yang diolah (Suhendra dkk, 2016). Semakin buruk kualitas air yang diolah, maka kemampuan media pembersih untuk menghasilkan air berkualitas juga rendah. Selain itu, kualitas air yang buruk dapat menurunkan efektivitas waktu penggunaan media dalam mengolah air gambut.

\section{PENUTUP}

Berdasarkan hasil pengujian, dapat dibuat beberapa kesimpulan sebagai berikut :

1. Pasir kerang efektif digunakan untuk mengolah air gambut menjadi air bersih. Pasir kerang dapat digunakan untuk menurunkan kadar warna dan meningkatkan kadar $\mathrm{pH}$ air gambut.

2. Efektivitas rata-rata pasir kerang untuk menurunkan kadar warna lebih baik dibanding media karbon aktif dan pasir kuarsa, sedangkan dalam meningkatkan $\mathrm{pH}$ lebih baik dibanding pasir kuarsa dan sedikit lebih rendah dibanding karbon aktif.

3. Hasil pengujian terbaik untuk pasir kerang diperoleh pada saat air pertama kali keluar dari instalasi pengolah air (0 menit) dengan efektivitas penjerapan warna 29,9\% yaitu dari 1.420 Pt.Co menjadi 995 Pt.Co, sedangkan kemampuan peningkatan $\mathrm{pH}$ dari 4,23 menjadi 7,38.

4. Efektivitas kerja pasir kerang dalam menurunkan kadar warna dan meningkatkan $\mathrm{pH}$ akan mengalami penurunan seiring dengan lamanya penggunaan pasir kerang dalam pengolahan air gambut. 
Penelitian lanjutan terhadap efektivitas kinerja pasir kerang dapat dilakukan terutama pada jumlah dosis yang digunakan dan lamanya efektivitas kerja terhadap berbagai parameter standar air bersih.

\section{DAFTAR PUSTAKA}

Makhmudah, N., \& Notodarmojo, S. (2010). Penyisihan Besi-Mangan, Kekeruhan Dan Warna Menggunakan Saringan Pasir Lambat Dua Tingkat Pada Kondisi Aliran Tak Jenuh Studi Kasus: Air Sungai Cikapundung. Jurnal Teknik Lingkungan, Vol. 16 No. 2, 150-159.

Muchlis, Utomo, K. P., \& Kadaria, U. (2017). Pemanfaatan Cangkang Kerang Darah (Anadara Granosa) dan Zeolit sebagai Media Filter Keramik untuk Pengolahan Air Gambut. Jurnal Mahasiswa Teknik lingkungan.

Peraturan Menteri Kesehatan RI No : 416/MENKES/PER/IX/1990 tentang : SyaratSyarat dan Pengawasan Kualitas Air.

Rachmah, N., \& Purwoto, S. (2014). Efektifitas Penurunan Mn dan Total Coliform Pada Air Sumur Gali Berbasis Zeolit. Jurnal Teknik WAKTU, Vol. 12 No. 1.

Rais, A., Fitrianingsih, Y., \& Ruliyansyah, A. (2017). Rancang Bangun Alat Pengolah Air Gambut dengan Sistem Filtrasi untuk Budidaya Perikanan. Jurnal Mahasiswa Teknik Lingkungan.

SNI.6989.80. (2011). Air dan Air Limbah - Bagian 80 : Cara Uji Warna Secara Spektofotometri. Jakarta: Badan Standarisasi Nasional.

Suhendra, \& Rianto, A. (2017). Karakteristik dan Teknik Pengolahan Air Gambut. Jakarta: Cakrawala Budaya.

Suhendra, Apriani, W., \& Sundari, E. M. (2016). Uji Kinerja Alat Penjerap Warna dan pH Air Gambut Menggunakan Arang Aktif Tempurung Kelapa. Positron, Vol. 6 No.1, 35-39.

Sumiharni, \& Susilo, G. E. (2009). Pengolahan Air Berkualitas Rendah menjadi Air Domestik Non Konsumsi. Jurnal Rekayasa, Vol. 13 No. 3, 291-298.

Widayat, W., \& Said, N. I. (2001). Pengolahan Air Gambut Secara Kontinyu. Jurnal Teknologi Lingkungan, Vol 2 No. 3, 214-222. 